\title{
KARANG TARUNA ENTERPRISE DEVELOPMENT DKI JAKARTA
}

\author{
${ }^{1}$ Meiryani, ${ }^{2}$ Jajat Sudrajat, ${ }^{3}$ Isanawikarya \\ ${ }^{1}$ Accounting Department, Faculty of Economics and Communication, Bina Nusantara University, \\ Jakarta, Indonesia 11480 \\ ${ }^{2}$ BINUS Entrepreneurship Center, Bina Nusantara University, Jakarta Indonesia 11480 \\ ${ }^{3}$ BINUS Entrepreneurship Center, Bina Nusantara University, Jakarta Indonesia 11480 \\ meiryani@binus.edu
}

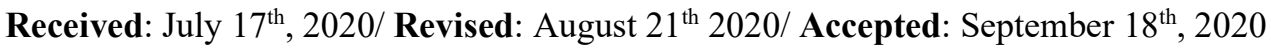

\begin{abstract}
The purpose of this activity is to motivate and inspire the DKI Jakarta Youth Organization through the theme of Entrepreneurship Development for the Jakarta Youth Organization. Participants in this activity were Binus Syahdan Campus Cleaning Service officers and Anggrek representing West Jakarta Youth Organization. This activity shows the enthusiasm of the participants because of their entrepreneurial development potential, because there are already several people who already have products, but are not optimal in their packaging and marketing, currently by optimizing social media networking alone. The results of this activity have several implications, including the following; First, the implications for planning and developing the training curriculum for MSMEs, Candidates for MSMEs and Communities and teaching materials for the EN001 Entrepreneurship course, with the collaboration method of lecturers, students and MSMEs in carrying out community service activities, by optimizing the implementation of the Entrepreneurship Student Activity Program (PKM-K) through Higher Education Grants in the Indonesian Student Business Competition Program (KBMI). Second, the implications for the education and training of lecturers by using an example method of direct practical application. Third, to inspire to increase cooperation with lecturers from different study programs, so that the output can make further proposals for funding other than the Binus grant. Fourth, the implications of choosing the right training / workshop method for participants and the community as well as increasing the synergy in the implementation of the Tridharma of Higher Education.
\end{abstract}

Keywords: motivation, inspiration and courage, entrepreneurial development, umkmgool website

\section{Introduction}

The Jakarta Manpower, Transmigration and Energy Agency noted that 162,416 workers in Jakarta had been laid off and sent home without wages as a result of Covid-19. In detail, 30,137 workers from 3,348 companies were laid off, while 132,279 workers from 14,697 companies were laid off without wages. The central government said it would accelerate the distribution of Pre-Work Cards in the midst of the Covid-19 outbreak. This effort was made to anticipate workers who were laid off and for daily workers whose income was affected by the Covid-19 outbreak (Kompas, 2020). Of the several employees who were laid off, including the DKI Jakarta Karang Taruna community who served as Cleaning Service officers at the Binus University campus, they experienced layoffs because their work contracts with Binus University partner companies ended, so they were not extended, based on the information we got from those concerned.

The Ministry of Manpower (Kemenaker) officially opened an entrepreneurship program entitled Entrepreneurship Incubation (Business Incubation In Wall) at the Center for Labor Market Development and Job Opportunity Expansion (BBPPK and PKK) Lembang, West Bandung. This is beneficial for workers affected by layoffs and being laid off in the midst of the Covid-19 pandemic. This business incubation entrepreneurship briefing activity was held for five days, 19 to 24 July 2020 
and was attended by 200 participants consisting of 19 people from Banten Province, 31 people from DKI Jakarta, 39 people in West Java, 10 people from the Special Region of Yogyakarta. , Central Java with 51 people and East Java with 50 people. (Republika, 2020).

We as lecturers, in carrying out the Community Service ( $\mathrm{PkM}$ ) program, want to contribute to providing motivation and enthusiasm to our Binus University cleaning service friends, both who are currently laid off and who are still working, to develop their entrepreneurship which has been initiated by their families. who reside in the village, as well as families in DKI Jakarta.

\section{Partner Profile Analysis}

Karang Taruna RW 08 Palmerah West Jakarta was established on October 28, 2011. With a mission to make RW 08 youth organizations more innovative, creative and independent. The area of West Jakarta Municipality has an area of 755 ha. According to 2004 statistical data, the land area designation consists of housing 495.82 ha; industry 1.23 ha; offices 93.79 ha; garden 12.63 ha; agriculture 7.06 ha; idle land 24.15 ha; and others 120.32 ha. Administratively, it consists of 6 urban villages, $61 \mathrm{RW}, 714 \mathrm{RT}, 48,776$ families, 193,787 people and with a population density of 25,667 people / km2.

Based on the ongoing PkM 2019 activities, the Cafe Betawi Project in Palmerah District is currently being built. This project is a collaboration between Binus University and Palmerah District with the support of Binus lecturers from various departments and competencies, so that the output of this project is an increase in the income of the UMKM community and PKK cadres assisted by BINUS University in the culinary business. The creation of a new Betawi culinary center in the Palmerah District area. Increasing the quality of culinary products produced by the UMKM community and PKK cadres assisted by BINUS University, but this project has not been implemented. This project plan inspires the role of Karang Taruna in helping to market the products and services produced by PKK and UKM so that Karang Taruna can develop their entrepreneurship, so we take the theme "Entrepreneurship Development of Karang Taruna DKI Jakarta".

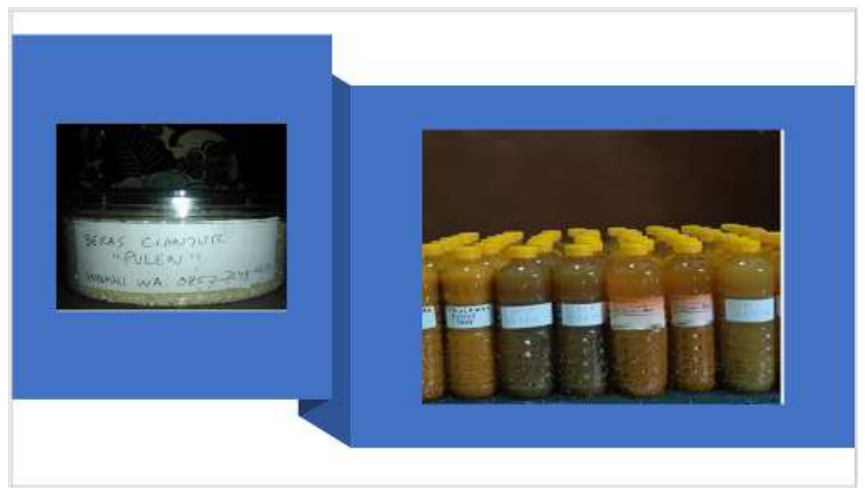

Figure 1. Example of Karang Taruna Products

\section{Partner Problems}

Currently, the basic problems experienced by the Youth Organization are as follows:

1. Entrepreneurship development, one of which starts from products and marketing.

2. There has not been an optimal mutually beneficial partnership between the PKK, UKM and Karang Taruna women communities

\section{Solution to Troubleshooting}

The problems of SMEs, especially the Karang Taruna Community can be overcome by increasing partnerships, especially in the marketing sector, so that the partnership between various 
communities can be carried out more quickly. Based on the ongoing PkM 2019 activities, even though the Cafe Betawi Project in Palmerah District has not been implemented, SMEs and the community are already running businesses. This project is a collaboration between Binus University and Palmerah District with the support of Binus lecturers from various departments and competencies. Improving the quality of culinary products produced by the SME community and PKK cadres assisted by BINUS University, will be more optimal if the role of the Youth Organization can help market the products and services produced by PKK and UKM women so that Karang Taruna can develop their entrepreneurship. In addition to using the Umkmgool website as a marketing solution for SME products, we will provide training in bookkeeping / accounting management, because whatever form of business and the amount of capital you have, making financial reports or bookkeeping is a must. With bookkeeping, every business activity will be recorded properly which can be used as a barometer and indicator to find out the company's performance that is being undertaken to support more productive, efficient and effective financial processing that can increase business profits or profits. (Rianti \& Swadarma, 2012)

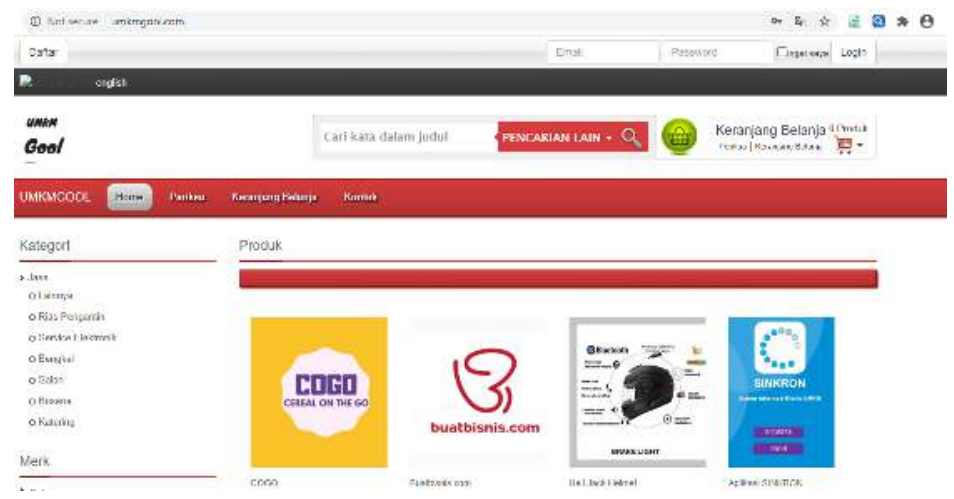

Figure 2. Confidence Karang Taruna Not successful Registration on the umkmgool website

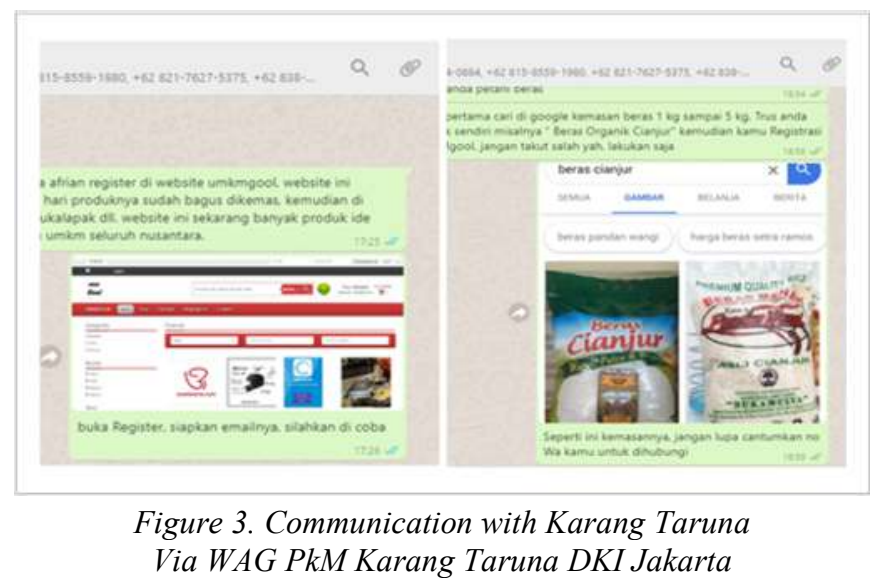

\section{Implementation Method}

Based on the observations that have been made, generally SMEs and Youth Organizations in DKI Jakarta, the main problem is in the field of marketing, media promotion, but some SMEs and Communities have used smartphones as marketing communication media. To solve marketing problems, one solution is to use the UMKMGool website for the Karang Taruna community. The implementation we did was creating a WAG Karang Taruna DKI Jakarta, then we invited one of the Youth Organization who works at the Binus University Campus as a Cleaning Service officer, to invite 
other Cleaning Service members who are located in West Jakarta to jointly discuss through WAG. They were invited to discuss developing their business apart from being a Cleaning Service officer, there are several people who have run their business helping their family members, and some are motivated to help develop their family business in the village. So that those who are enthusiastic and motivated want to do entrepreneurship, we help directly to market products to practice developing their entrepreneurial spirit.

\section{Conclusion}

The purpose of this activity is to motivate and inspire the DKI Jakarta Youth Organization through the theme of Entrepreneurship Development for the Jakarta Youth Organization with the topic / material "Understanding Entrepreneurship through Registration on the UMKMGool Website". Participants in this activity were Binus Syahdan Campus Cleaning Service officers and Anggrek representing West Jakarta Youth Organization. This activity shows the enthusiasm of the participants because of their entrepreneurial development potential, because there are already several people who already have products, but are not optimal in their packaging and marketing, currently by optimizing social media networking alone. The results of this activity have several implications, including the following; First, the implications for planning and developing the training curriculum for MSMEs, Candidates for MSMEs and Communities and teaching materials for the EN001 Entrepreneurship course, with the collaboration method of lecturers, students and MSMEs in carrying out community service activities, by optimizing the implementation of the Entrepreneurship Student Activity Program (PKM-K) through Higher Education Grants in the Indonesian Student Business Competition Program (KBMI). Second, the implications for the education and training of lecturers by using an example method of direct practical application. Third, to inspire to increase cooperation with lecturers from different study programs, so that the output can make further proposals for funding other than the Binus grant. Fourth, the implications of choosing the right training / workshop method for participants and the community as well as increasing the synergy of the implementation of the Tridharma of Higher Education, adjusted to the facilities owned by the target object, currently using the WA Group media, they are familiar with using it.

\section{References}

Rianti, A. A., \& Swadarma, D. (2012). Pembukuan Sederhana Usaha Dagang dan Jasa (Untuk Perusahaan Kecil dan Menengah). Jakarta: Laskar Aksara.

Sari, Nursita. (Kompas, 2020), "PHK Massal di Tengah Pandemi Covid-19 dan Upaya Pemerintah Berikan Insentif". https://megapolitan.kompas.com/read/2020/04/06/06231941/phk-massaldi-tengah-pandemi-covid-19-dan-upaya-pemerintah-berikan?page=all .

Hafizhah, Haura (Republika, 2020), " Ringankan Korban PHK Menaker Buka Program Kewirausahaan.https://republika.co.id/berita/qdrlg1423/ringankan-korban-phk-menaker-bukaprogram-kewirausahaan 